\title{
Sistem Pendukung Keputusan Referensi Pemilihan Tujuan Jurusan Teknik Di Perguruan Tinggi bagi Siswa Kelas XII IPA Mengunakan Metode AHP
}

\author{
Arief Herdiansah \\ Teknik Informatika, Universitas Muhammadiyah Tangerang \\ E-Mail: arief_herdiansah@umt.ac.id
}

\begin{abstract}
ABSTRAK
Dari proses wawancara yang peneliti lakukan kepada beberapa siswa kelas XII IPA sekolah menengah atas, ditemui cukup banyaksiswayang memiliki keraguan dalam menentukan jurusan pada saat nanti melanjutkan pendidikan ke tingkat perguruan tinggi khususnya yang ingin melajutkan kuliah pada fakultas teknik. Sebagian dari mereka ragu apakah keinginan untuk dapat berkuliah pada salah satu jurusan di fakultas teknik yang diinginkan dapat mereka jalani dengan lancar jika melihat pencapaian hasil proses belajar yang saat ini mereka ikuti di sekolah menengah atas. Berdasarkan hal tersebut, peneliti melakukan penelitian untuk membangun sebuah sistem pendukung keputusan (SPK) yang dapat membantu memberikan referensi kepada siswa mengenai jurusan pada fakultas teknik yang sesuai dengan minat dan bakat siswa tersebut. Peneliti menggunakan SWOT analisis untuk menganalisa kondisi dan kebutuhan pengguna. Penelitian dilakukan disalah satu sekolah menengah atas di kota Tangerang dan pengambilan data kriteria dan bobotnya dari lima ketua program studi pada fakultas teknik Universitas Muhammadiyah Tangerang. SPK dikembangkan menggunakan metode AHP, metode pengembangan sistem prototipe dan diuji dengan metode pengujian black box. Berdasarkan hasil uji coba SPK ini, telah didapat referensi pemilihan jurusan yang cukup memuaskan siswa yang menjadi contoh uji.
\end{abstract}

Kata Kunci: SPK, AHP, SWOT, Jurusan, Prototipe

\begin{abstract}
Based on the results of interviews conducted by researchers to students of class XII science in senior high school, quite a lot of students who are not sure in determining the majors when going to continue their education to university, especially those who want to continue studying at the faculty of engineering. Some of them are doubtful whether they want to be able to study at one of the majors in the faculty of engineering that they want can go smoothly if they see the achievement of the learning process that they are currently attending in senior high school. Based on this, the researchers conducted research to build a decision support system (DSS) that can help provide references to students regarding majors in the engineering faculties that best suit the students' interests and talents. The researcher uses SWOT analysis to analyze current conditions and user needs. The study was conducted at one senior high school in Tangerang city and the data collection criteria from five departments head at the faculty of engineering at Muhammadiyah University Tangerang. DSS was developed using the AHP method, the prototype system development method and tested by the black box testing method. From the results of this DSS trial, it has been obtained a reference to the selection of majors that are sufficient to satisfy the students who become test samples.
\end{abstract}

Keywords: SPK, AHP, SWOT, Department, Prototype

Author Korespondensi (Arief Herdiansah)

Email : arief_herdiansah@umt.ac.id 


\section{PENDAHULUAN}

Pengenalan jurusan atau program studi perguruan tinggi pada siswa kelas XII Sekolah Menengah Atas saat ini dirasa masih kurang. Sedangkan proses penentuan jurusan yang akan ditempuh pada saat melanjutkan pendidikan di perguruan tinggi merupakan sebuah keputusan besar, karena merupakan sebuah keputusan yang berpengaruh jangka panjang yang akan menentukan kehidupan siswa tersebut dimasa yang akan datang. Dalam perspektif calon mahasiswa, keputusan memilih program studi di suatu perguruan tinggi dianggap berpotensi untuk merubah kehidupan individu. Karena itu, keputusan memilih program studi tersebut merupakan isu yang penting [1].

Cukup banyak kasus mahasiswa yang merasa tidak dapat mengikuti proses belajar-mengajar di bangku kuliah karena ternyata kemampuan akademik yang dimiliki kurang cocok dengan minat dalam mengambil jurusan/program studi, hal tersebut menyebabkan beberapa mahasiswa mengambil keputusan untuk pindah jurusan/program studi pada perguruan tinggi yang lain yang sama, bahkan ada beberapa yang harus pindah ke perguruan tinggi lain.

Berdasarkan hal tersebut peneliti melakukan penelitian untuk mengambangkan sebuah aplikasi SPK yang dapat membantu siswa kelas XII khususnya jurursan IPA sekolah menengah atas, yang masih memiliki keraguan dalam menentukan jurusan pada saat nanti melanjutkan pendidikan ke tingkat perguruan tinggi khususnya yang ingin melajutkan kuliah pada fakultas teknik. Penelitian ini mengambil contoh uji pada beberapa siswa kelas XII IPA, dan menggunkan kriteria dan bobot nya dari 5 (lima) ketua program studi fakultas teknik Universitas Muhammadiyah Tangerang.

Sistem adalah jaringan prosedur yang dibuat menurut pola yang terpadu untuk melaksanakan kegiatan pokok perusahaan [2]. Sistem informasi adalah suatu hal yang saling berhubungan satu dengan lainnya yang akhirnya menghasilkan sebuah informasi/data yang berguna bagi orang yang dituju sesuai dengan peruntukannya. Perkembangan sistem informasi tidak terlepas dari perkembangan teknologi informasi. Penelitian ini adalah pengembangan sistem informasi SPK yang menggunakan metode AHP, dikembangkan menggunakan model pengembangan sistem prototipe serta diuji menggunakan pengujian black box.

Penelitian yang dilakukan menggunakan siklus SDLC (Software Development Life Cycle) dengan model prototipe. Model SDLC merupakan metode pendekatan secara sistematis dan urut mulai level analisis sistem lalu menuju ke tahap desain sistem, implementasi sistem, uji coba, dan pemeliharaan [3].

\subsection{Analytic Hierarchy ProcessAHP}

AHP merupakan teknik keputusan multikriteria yang menggunakan pendekatan hierarkis untuk mengevaluasi nilai kepercayaan [4]. Metode AHP mengasumsikan bahwa pembuat keputusan dapat memberikan estimasi poin yang tepat dari preferensi mereka untuk alternatif. Oleh karenanya metode ini tidak cocok untuk skenario ketika ada ketidakpastian yang tinggi dalam penilaian pengambil keputusan [5]. Dalam kasus ini ketidakpastian tidak tinggi karena perhitungan mengacu pada pencapaian hasil pembelajaran siswa saja.

\subsection{Prototipe}

Model pengembangan sistem prototipe adala sebuah model pengembangan pengembangan perangkat lunak (software) yang dapat membuat sistem dikembangkan dengan cara cepat dan sesuai dengan kebutuhan pengguna serta teruji dengan baik karena pengujian terhadap model kerja dari aplikasi baru melalui proses interaksi dan berulangulang.

Implementasi prototipe akan memberikan contoh pemodelan untuk skema data fitur perancangan yang diusulkan [6]. Model prototipe merupakan proses berulang dari proses communication, quick plan, modeling quick design, contrction prototype, development delivery \& feddback serta communication [7].

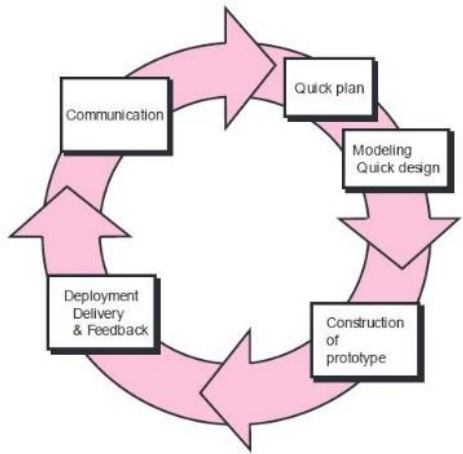

Gambar 1. model prototipe [7] 


\subsection{UML (Unifield Modeling Language)}

UML adalah 'bahasa' pemodelan untuk sistem atau perangkat lunak yang berparadigram 'berorientasi objek'. Pemodelan (modeling) sesungguhnya digunakan untuk penyederhanaan permasalahan-permasalahan yang kompleks sedemikian rupa sehingga lebih mudah dipelajari dan dipahami [8]. UML menyediakan sembilan jenis diagram, yang lain menyebutkan delapan karena ada beberapa diagram yang digabung, misanya diagram komunikasi, diagram urutan dan diagram pewaktuan digabung menjadi diagram interaksi [9].

Dalam melakukan penelitian ini, peneliti menggunakan beberapa literatur studi dari penelitian sebelumnya, antara lain:

1. Rahmayu, $\mathbf{M}$ dan Serli, K.R dalam penelitian yang berjudul "Sistem Pendukung Keputusan Pemilihan Jurusan pada SMK Putra Nusantara Jakarta Menggunakan Metode Analytical Hierarchy Process (AHP)". Penelitian ini merupakan penelitian untuk menilai minat, bakat serta kemampuannya seorang siswa pada pembelajaran di jurusan tertentu di SMA tempat penelitian, agar tidak terjadi salah dalam memilih jurusan yang di SMK. Pemilihan jurusan bagi calon siswa SMA/SMK adalah awal dari pemilihan karir ke depannya. Analisa kebutuhan dalam penelitian ini dilakukan berdasarkan pengamatan dan pemahaman peneliti yang bersangkutan [10].

2. Irawan, S.A. dalam penelitian yang berjudul "Sistem Pendukung Keputusan Pemilihan Jurusan di SMA Islam Sudirman Ambarawa Menggunakan Metode Analytical Hierarchy Process (AHP)". Penelitian merupakan penelitian yang dilakukan dalam rangka membantu guru BK (Bimbingan Konseling) memberikan masukan kepada siswa untuk mengetahui jurusan yang sesuai dengan minat dan bakat siswa tersebut, mengingat pemilihan jurusan bagi siswa SMA merupakan awal dari pemilihan karir siswa kedepannya. Peranangan sistem menggunakan DFD (Data Flow Diagram) dan sistem dibangun menggunakan aplikasi VB 6.0 [11].
3. Frieyadie, dalam penelitian yang berjudul "Penerapan Metode AHP Untuk Membantu Siswa Memilih Jurusan yang Tepat di SMK". Penelitian ini merupakan penelitian yang bertujuan sebagai alternative untuk membantu pihak sekolah dalam menentukan keputusan pemilihan jurusan siswa sesuai dengan kriteria. Melakukan penilaian dari setiap kreteria untuk pemilihan jurusan dan menjadikan suatu Pendukung Keputusan untuk pemilihan jurusan agar mendapatkan siswa yang memenuhi kriteria dengan cepat dan tepat [12].

\section{METODOLOGI}

Metodologi penelitian yang digunakan antara lain:

\subsection{Analisis SWOT}

Annalisis SWOT adalah akronim untuk kekuatan (Strenghts), kelemahan (Weakness), peluang (Opportunities), dan ancaman (Threats) dari eksternal perusahaan. SWOT digunakan untuk menilai kekuatan-kekuatan dan kelemahan-kelemahan dari sumber-sumber daya yang dimiliki perusahaan dan kesempatankesempatan eksternal dan tantangan-tantangan yang dihadapi [13].

Analisis SWOT dari penelitian ini, antara lain:

1. Strengths, kekuatan/kelebihan dari SPK yang dikembangkan antar lain, sebagai SPK yang akuratkarena kriteria dan pembobotannya diambil dari nara sumber yang terpercaya, dalam hal ini 5 orang kaprodi di fakultas teknik Universitas Muhammadiyah Tangerang.

2. Weaknesses, kelemahan/kekurangan dari SPK yang dikembangkan adalah hanya untuk prodi yang ada di fakultas teknik.

3. Opportunities, peluang kedepan dari SPK yang dikembangkan, hendaknya ditambah modul yang memungkinkan memproses kebutuhan siswa yang ingin melanjutkan kuliah di fakultas selain fakultas teknik.

4. Threats,jika ada pihak luar yang tidak bertanggung jawab merubah bobot kriteria dari SKP yang dibuat dapat menjadi ncaman dari pihak luar terhadap dari SPK yang dikembangkan karena hasil dari proses sistem menjadi tidak akurat, oleh karenanya pengguna harus dapat menjaga kerahasiaan 
dari user name dan password administrator sistem.

\subsection{Pengumpulan Data}

Peneliti ini menggunakan metode wawancara dan metode sampling. Metode wawancara dilakukan untuk melakukan pengambilan data kriteria dan bobotnya dari lima ketua program studi pada fakultas teknik Universitas Muhammadiyah Tangerang, sebagai dasar dari SPK yang dikembangkan.Metode analisa berkas dilakukan untuk melakukan analisa sampling untuk mengambil data beberapa siswa kelas XII IPA sekolaha menengah atas yang ingin melanjutkan studi lanjut di perguruan tinggi/universitas fakultas teknik.

\subsection{Perancangan Sistem}

Peneliti menggunakan UML untuk membuat perancangan sistem, antara lain use case diagram, sequence diagramdan class diagram.

\subsection{Pengembangan Sistem}

Penelitian ini menggunakan bahasa pemrograman PHP dan database MySql dalam proses pembagunan SPK referensi pemilihan jurusan teknik untuk keperluan pemilihan program studi setelah lulus dari sekolah menengah atas.

\subsection{Uji Coba Sistem}

Sistem yang dibuat diuji menggunakan metode pengujian black box. Pengujian blackbox disebut juga pengujian perilaku dimana pengujian ini berfokus pada persyaratan fungsional dari sebuah perangkat lunak tanpa perlu mengetahui detail proses yang berjalan didalam aplikasi tersebut, jadi penguji/pengguna hanya akan mengetahui masukan (input) dan keluaran (output) dari aplikasi yang diuji.

\section{HASIL DAN PEMBAHASAN}

Langkah pertama yang dilakuakn dalam proses pembangunan sebuah SPK AHP adalah membentuk struktur hirarki yang mempunyai tujuan untuk memecah suatu masalah yang kompleks, kemudian disusun menjadi suatu bentuk hirarki. Suatu struktur hirarki terdiri dari beberapa elemen yang dikelompokan dalam beberapa tingkatan (level) Tingkatan teratas merupakan tujuan akhir sistem yang dibangun, tingkatan berikutnya terdiri dari beberapa kriteria untuk dijadikan dasar menilai atau mempertimbangkan alternatif-alternatif yang ada dan menentukan alternatif-alternatif yang telah ditetapkan. Kriteria dan alternatif merupakan 2 komponen dasar dalam pengembagan SPK AHP. Dibawah ini gambar struktur hirarki sistem yang dikembangkan dalam penelitian ini:

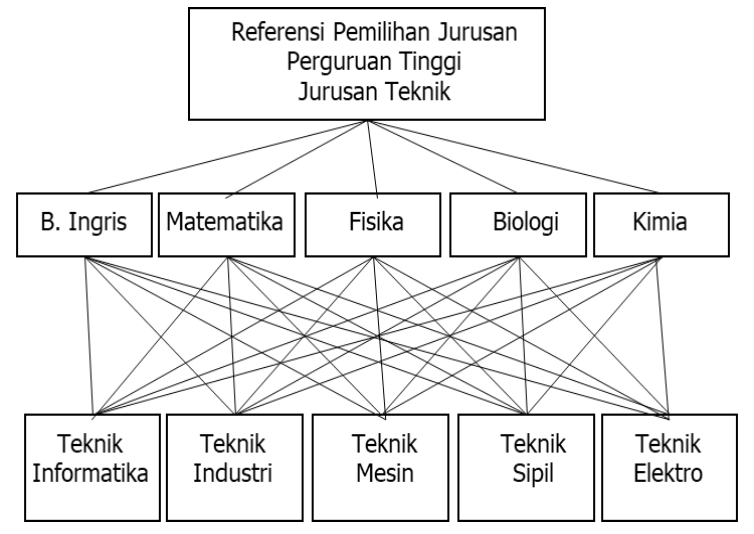

Gambar 2. Struktur Hirarki SPK

Berikut ini hasil perancangan, pembangunan dan pengujian SPK referensi pemilihan tujian jurusan teknik di perguruan tinggi bagi siswa kelas XII IPA menggunakan metode AHP:

\subsection{Perhitungan Sample Data}

\section{Level 1 \\ Nama : Raja Almas \\ Kelas : XII IPA}

Tabel 1. Nilai Mata Pelajaran dan Bobot

\begin{tabular}{|c|c|c|c|c|c|}
\hline & $\begin{array}{c}\text { B.Inggr } \\
\text { is }\end{array}$ & $\begin{array}{c}\text { Matemati } \\
\text { ka }\end{array}$ & $\begin{array}{c}\text { Fisik } \\
\text { a }\end{array}$ & $\begin{array}{c}\text { Biolo } \\
\text { gi }\end{array}$ & $\begin{array}{c}\text { Kimi } \\
\text { a }\end{array}$ \\
\hline Nilai & 80 & 80 & 76 & 83 & 87 \\
\hline $\begin{array}{c}\text { Bob } \\
\text { ot }\end{array}$ & 3 & 3 & 2 & 4 & 5 \\
\hline
\end{tabular}

Tabel 2.Keterangan Bobot

\begin{tabular}{|c|c|}
\hline Bobot & Keterangan \\
\hline 1 & Rendah \\
\hline 2 & Rendah Menegah \\
\hline 3 & Menengah \\
\hline 4 & Menengah Utama \\
\hline 5 & Utama \\
\hline
\end{tabular}


Skala penilaian yang terdapat di table diatas digunakan untuk memberikan nilai matriks perbandingan berpasangan untuk mengahasilkan prioritas (bobot kepentingan elemen) setiap kriteria dan sub-kriteria.

Pembandingan kriteria dilakukan dengan mengisi nilai bobotnya berdasarkan tingkat kepentingan dari kriteria tersebut (pair-wise comparation). Kriteria yang dinilai adalah Bahasa Inggris, Matematika, Fisika, Kimia dan Biologi.

Tabel 3. Matrik Faktor Perbandingan Hirarki Untuk Semua Kriteria yang disederhanakan

\begin{tabular}{|c|c|c|c|c|c|}
\hline Kriteria & $\begin{array}{c}\text { Bahasa } \\
\text { Inggris } \\
(3)\end{array}$ & $\begin{array}{c}\text { Mate } \\
\text { matik } \\
\mathrm{a}(3)\end{array}$ & $\begin{array}{c}\text { Fisika } \\
(2)\end{array}$ & $\begin{array}{c}\text { Biolo } \\
\text { gi (4) }\end{array}$ & $\begin{array}{l}\text { kimia } \\
(5)\end{array}$ \\
\hline $\begin{array}{c}\text { B.Inggr } \\
\text { is(3) }\end{array}$ & 1 & 1 & 3 & $1 / 3$ & $1 / 5$ \\
\hline $\begin{array}{c}\text { Matem } \\
\text { atika(3) }\end{array}$ & 1 & 1 & 3 & $1 / 3$ & $1 / 5$ \\
\hline $\begin{array}{c}\text { Fisika } \\
(2)\end{array}$ & $1 / 3$ & $1 / 3$ & 1 & $1 / 5$ & $1 / 7$ \\
\hline $\begin{array}{c}\text { Biologi } \\
(4)\end{array}$ & 3 & 3 & 5 & 1 & $1 / 3$ \\
\hline $\begin{array}{c}\text { Kimia } \\
(5)\end{array}$ & 5 & 5 & 7 & 3 & 1 \\
\hline Total & 11 & 11 & 22 & 5 & 2 \\
\hline
\end{tabular}

Menormalkan matriks dengan membagi nilai masing-masing sel pada tabel 3 dengan jumlah masing-masing kolomnya. Maka, akan diperoleh bobot relatif yang dinormalkan . Nilai eigen vector dihasilkan dari rata-rata bobot relatif untuk setiap baris. Maka, hasil yang diperoleh dari perhitungan dapat dilihat pada tabel 4 berikut:

Tabel 4. Matriks Faktor Pembobotan Hirarki untuk Semua Kriteria yang Dinormalkan

\begin{tabular}{|c|c|c|c|c|c|c|c|}
\hline Kriteria & B.Inggris & Mat & Fis & Bio & Kimia & Total & $\begin{array}{l}\text { Eigen } \\
\text { Vektor }\end{array}$ \\
\hline B.Inggris & $\begin{array}{c}0.0967741 \\
94\end{array}$ & $\begin{array}{c}0.0967741 \\
94\end{array}$ & $\begin{array}{c}0.1578947 \\
37\end{array}$ & $\begin{array}{c}0.068493 \\
151\end{array}$ & $\begin{array}{c}0.1065989 \\
8\end{array}$ & $\begin{array}{c}0.52653 \\
5\end{array}$ & $\begin{array}{c}0.1053070 \\
5\end{array}$ \\
\hline Mat & $\begin{array}{c}0.0967741 \\
94 \\
\end{array}$ & $\begin{array}{c}0.0967741 \\
94 \\
\end{array}$ & $\begin{array}{c}0.1578947 \\
37 \\
\end{array}$ & $\begin{array}{c}0.068493 \\
151 \\
\end{array}$ & $\begin{array}{c}0.1065989 \\
8 \\
\end{array}$ & $\begin{array}{c}0.52653 \\
5 \\
\end{array}$ & $\begin{array}{c}0.1053070 \\
5 \\
\end{array}$ \\
\hline Fis & $\begin{array}{c}0.0322580 \\
65 \\
\end{array}$ & $\begin{array}{c}0.0322580 \\
65 \\
\end{array}$ & $\begin{array}{c}0.0526315 \\
79 \\
\end{array}$ & $\begin{array}{c}0.041095 \\
89 \\
\end{array}$ & $\begin{array}{c}0.0761421 \\
3 \\
\end{array}$ & $\begin{array}{c}0.23438 \\
6 \\
\end{array}$ & $\begin{array}{c}0.0468771 \\
5 \\
\end{array}$ \\
\hline Bio & $\begin{array}{c}0.2903225 \\
81\end{array}$ & $\begin{array}{c}0.2903225 \\
81\end{array}$ & $\begin{array}{c}0.2631578 \\
95\end{array}$ & $\begin{array}{c}0.205479 \\
452\end{array}$ & $\begin{array}{c}0.1776649 \\
7\end{array}$ & $\begin{array}{c}1.22694 \\
7\end{array}$ & 0.2453895 \\
\hline Kim & $\begin{array}{c}0.4838709 \\
68\end{array}$ & $\begin{array}{c}0.4838709 \\
68\end{array}$ & $\begin{array}{c}0.3684210 \\
53\end{array}$ & $\begin{array}{c}0.616438 \\
356\end{array}$ & $\begin{array}{c}0.5329949 \\
2\end{array}$ & $\begin{array}{c}2.48559 \\
6\end{array}$ & $\begin{array}{c}0.4971192 \\
5\end{array}$ \\
\hline
\end{tabular}

Dari hasil perhitungan diatas di dapatkan hasil presentase kriteria berikut:

B.Inggris $=10 \%$, Matematika $=10 \%$, Fisika $=5 \%$, Biologi $=25 \%$, dan Kimia $50 \%$ 
Proses selanjutnya adalah menghitung nilai eigen maksimum ( $\lambda$ maksimum $)$ sebagaimana tabel 5 berikut ini:

Tabel 5. eigen maksimum ( $\lambda$ maksimum $)$

\begin{tabular}{|l|c|c|r|}
\hline & \multicolumn{2}{|l|}{$\Lambda$} \\
\hline B.Inggris & 0.53 & 0.1 & 5.3 \\
\hline Matematika & 0.53 & 0.1 & 5.3 \\
\hline Fisika & 0.23 & 0.04 & 5.75 \\
\hline Biologi & 1.23 & 0.25 & 4.92 \\
\hline Kimia & 2.48 & 0.5 & 4.96 \\
\hline \multicolumn{2}{|c|}{$\Sigma \lambda$} & & 26.23 \\
\hline $\begin{array}{l}2 \max =\Sigma \lambda / \\
6\end{array}$ & & $\underline{5.246}$ \\
\hline
\end{tabular}

Selanjtnya menentukan nilai $\mathrm{CR}$, sebegaiman perhitungan dibawah ini:

$$
\mathrm{CI}=\frac{\lambda \text { maksimum }-\mathrm{n}}{\mathrm{n}-1}=\frac{5.246-5}{5-1}=0.0615
$$

Untuk RI = 1.24 maka

$$
\mathrm{CR}=\frac{\mathrm{CI}}{\mathrm{RI}}=\frac{0.0615}{1.24}=\mathbf{0 . 0 5 4 9}
$$

Karena CR $<0,1000$ maka hasil perhitungan kriteria adalah konsisten

\subsection{Level 2}

Ketahui bobot \& persentase jurusan berdasarkan nilai Standar nilai minimum per jurusan \& Nilai Siswa.

Tabel 6. Nilai Min Perjurusan \& Nilai Siswa/i

\begin{tabular}{|c|c|c|c|c|c|}
\hline Jurusan & $\begin{array}{c}\text { B.ingg } \\
\text { ris }\end{array}$ & $\begin{array}{c}\text { Matema } \\
\text { tika }\end{array}$ & $\begin{array}{c}\text { Fisi } \\
\text { ka }\end{array}$ & $\begin{array}{c}\text { Biolo } \\
\text { gi }\end{array}$ & $\begin{array}{c}\text { Kim } \\
\text { ia }\end{array}$ \\
\hline $\begin{array}{c}\text { T.Informa } \\
\text { tika }\end{array}$ & 79 & 75 & 73 & 68 & 67 \\
\hline T.Industri & 74 & 72 & 70 & 70 & 70 \\
\hline T.Mesin & 75 & 70 & 75 & 65 & 75 \\
\hline T.Sipil & 74 & 70 & 76 & 60 & 60 \\
\hline T.Elektro & 73 & 73 & 70 & 60 & 65 \\
\hline Nilai & 80 & 80 & 76 & 83 & 87 \\
\hline
\end{tabular}

Tabel 7. Bobot Nilai Akademik Calon Mahasiswa Baru berdasarkan standar nilai minimum per jurusan

\begin{tabular}{|c|c|c|c|c|c|}
\hline Jurusan & $\begin{array}{c}\text { B.ingg } \\
\text { ris }\end{array}$ & $\begin{array}{c}\text { Matema } \\
\text { tika }\end{array}$ & $\begin{array}{c}\text { Fisi } \\
\text { ka }\end{array}$ & $\begin{array}{c}\text { Biolo } \\
\text { gi }\end{array}$ & $\begin{array}{c}\text { Kim } \\
\text { ia }\end{array}$ \\
\hline $\begin{array}{c}\text { T.Informa } \\
\text { tika }\end{array}$ & 3 & 3 & 2 & 3 & 3 \\
\hline T.Industri & 1 & 2 & 1 & 4 & 4 \\
\hline T.Mesin & 2 & 1 & 3 & 2 & 5 \\
\hline T.Sipil & 2 & 1 & 4 & 1 & 1 \\
\hline T.Elektro & 1 & 3 & 1 & 1 & 2 \\
\hline
\end{tabular}

\subsection{Perhitungan Faktor Evaluasi \& Matriks} Perbandingan Berpasangan Pada Setiap Kriteria

i. Perhitungan faktor evaluasi \& matriks berpasangan pada kriteria bahasa inggris, sebagai contoh adalah perhitungan faktor evaluasi \& matriks berpasangan pada kriteria bahasa inggris, sebagai berikut: menyusun alternatif jurusan dengan menggunakan matriks perbandingan berpasangan (tabel 8).

Tabel 8. Matriks Faktor Evaluasi Untuk Kriteria Bahasa Inggris

\begin{tabular}{|c|c|c|c|c|c|}
\hline Jurusan & $\begin{array}{c}\text { T.Informa } \\
\text { tika } \\
(3)\end{array}$ & $\begin{array}{c}\text { T.Indus } \\
\text { tri } \\
(1)\end{array}$ & $\begin{array}{c}\text { T.Mes } \\
\text { in } \\
(2)\end{array}$ & $\begin{array}{c}\text { T.Si } \\
\text { pil } \\
(2)\end{array}$ & $\begin{array}{c}\text { T.Elek } \\
\text { tro } \\
(1)\end{array}$ \\
\hline $\begin{array}{c}\text { T.Informatik } \\
\text { a(3) }\end{array}$ & 1 & 5 & 3 & 3 & 5 \\
\hline T.Industri(1) & $1 / 5$ & 1 & $1 / 3$ & $1 / 3$ & 1 \\
\hline T.Mesin(2) & $1 / 3$ & 3 & 1 & 1 & 3 \\
\hline T.Sipil(2) & $1 / 3$ & 3 & 1 & 1 & 3 \\
\hline T.Elektro(1) & $1 / 5$ & 1 & $1 / 3$ & $1 / 3$ & 1 \\
\hline Total & 2 & 13 & 5.6 & 5.6 & 13 \\
\hline
\end{tabular}

ii. Menormalkan matriks dengan membagi nilai masing-masing sel dengan jumlah kolomnya. Akan diperoleh bobot relatif yang dinormalkan. Nilai eigen vector dihasilkan dari rata-rata bobot relatif untuk setiap baris. 
Tabel 9.Matriks Faktor Evaluasi untuk

Kriteria Bahasa Inggris yang dinormalkan.

\begin{tabular}{|c|c|c|c|c|c|c|c|}
\hline Jurusan & $\begin{array}{c}\text { T.Inf } \\
\text { ormat } \\
\text { ika }\end{array}$ & $\begin{array}{c}\text { T.In } \\
\text { dust } \\
\text { ri }\end{array}$ & $\begin{array}{l}\text { T.Me } \\
\text { sin }\end{array}$ & $\begin{array}{c}\text { T.Si } \\
\text { pil }\end{array}$ & $\begin{array}{c}\text { T.El } \\
\text { ektr } \\
\text { o }\end{array}$ & $\begin{array}{c}\text { Tot } \\
\text { al }\end{array}$ & $\begin{array}{c}\text { Eig } \\
\text { en } \\
\text { Vec } \\
\text { tor }\end{array}$ \\
\hline $\begin{array}{l}\text { T.Infor } \\
\text { matika }\end{array}$ & $\begin{array}{c}0.483 \\
8709 \\
68\end{array}$ & $\begin{array}{l}0.38 \\
461 \\
538\end{array}$ & $\begin{array}{c}0.529 \\
4117 \\
6\end{array}$ & $\begin{array}{c}0.52 \\
941 \\
176 \\
5\end{array}$ & $\begin{array}{c}0.38 \\
461 \\
538\end{array}$ & $\begin{array}{l}2.31 \\
192 \\
527\end{array}$ & $\begin{array}{l}0.46 \\
238 \\
505\end{array}$ \\
\hline $\begin{array}{l}\text { T.Indus } \\
\text { tri }\end{array}$ & $\begin{array}{c}0.096 \\
7741 \\
94\end{array}$ & $\begin{array}{l}0.07 \\
692 \\
308\end{array}$ & $\begin{array}{c}0.058 \\
8235 \\
3\end{array}$ & $\begin{array}{c}0.05 \\
882 \\
352 \\
9\end{array}$ & $\begin{array}{l}0.07 \\
692 \\
308\end{array}$ & $\begin{array}{l}0.36 \\
826 \\
741\end{array}$ & $\begin{array}{l}0.07 \\
365 \\
348\end{array}$ \\
\hline $\begin{array}{c}\text { T.Mesi } \\
\mathrm{n}\end{array}$ & $\begin{array}{c}0.161 \\
2903 \\
23\end{array}$ & $\begin{array}{l}0.23 \\
076 \\
923\end{array}$ & $\begin{array}{c}0.176 \\
4705 \\
9\end{array}$ & $\begin{array}{c}0.17 \\
647 \\
058 \\
8\end{array}$ & $\begin{array}{l}0.23 \\
076 \\
923\end{array}$ & $\begin{array}{l}0.97 \\
576 \\
996\end{array}$ & $\begin{array}{l}0.19 \\
515 \\
399\end{array}$ \\
\hline T.Sipil & $\begin{array}{c}0.161 \\
2903 \\
23\end{array}$ & $\begin{array}{l}0.23 \\
076 \\
923\end{array}$ & $\begin{array}{c}0.176 \\
4705 \\
9\end{array}$ & $\begin{array}{c}0.17 \\
647 \\
058 \\
8\end{array}$ & $\begin{array}{l}0.23 \\
076 \\
923\end{array}$ & $\begin{array}{l}0.97 \\
576 \\
996\end{array}$ & $\begin{array}{l}0.19 \\
515 \\
399\end{array}$ \\
\hline T.Elektro & $\begin{array}{c}0.096774 \\
194\end{array}$ & $\begin{array}{c}0.0769 \\
2308\end{array}$ & $\begin{array}{c}0.058823 \\
53\end{array}$ & $\begin{array}{l}0.0588 \\
23529\end{array}$ & $\begin{array}{c}0.0769 \\
2308\end{array}$ & $\begin{array}{c}0.3682 \\
6741\end{array}$ & $\begin{array}{c}0.0736 \\
5348\end{array}$ \\
\hline
\end{tabular}

iii. Menghitung nilai eigen maksimum ( $\lambda$ maksimum )

Tabel 10.Eigen Maksimum Bahasa Inggris

\begin{tabular}{|l|l|c|r|}
\hline \multicolumn{2}{|l|}{} & \multicolumn{1}{c|}{$\Lambda$} \\
\hline T.Informatika & 2.31 & 0.46 & 5.02173913 \\
\hline T.Industri & 0.37 & 0.07 & 5.28571429 \\
\hline T.Mesin & 0.98 & 0.2 & 4.9 \\
\hline T.Sipil & 0.98 & 0.2 & 4.9 \\
\hline T.Elektro & 0.37 & 0.074 & 5 \\
\hline \multicolumn{2}{|c|}{$\Sigma \lambda$} & & 25.1074534 \\
\hline $\begin{array}{l}2 \max =\Sigma \lambda / \\
5\end{array}$ & & 5.02149068 \\
\hline
\end{tabular}

iv. Menghitung nilai indeks konsistensi. Karena matriks berordo 5 (yakni terdiri dari 5 jurusan fakultas teknik), maka nilai indeks konsistensi yang diperoleh adalah:

$$
\begin{aligned}
\mathrm{CI} & =\frac{\lambda \text { maksimum }-\mathrm{n}}{\mathrm{n}-1} \\
& =\frac{5.02149068-5}{4}=0.0053726
\end{aligned}
$$

Untuk $\mathrm{n}=5$ maka RI $=1.12$

$$
\mathrm{CR}=\frac{\mathrm{CI}}{\mathrm{RI}}=\frac{0.0053726}{1.12}=0.004797
$$

Karena CR $<$ 0,1000 maka hasil perhitungan kriteria adalah konsisten

v. Dari hasil perhitungan diatas diketahui bahwa urutan prioritas untuk kriteria Nilai Bahasa Inggris pada masing-masing Jurusan Teknik adalah Teknik Informatika dengan bobot 46\%, Teknik Industri dengan bobot 7\%, Teknik Mesin dengan bobot 2\%, Teknik Sipil dengan bobot $2 \%$ dan Teknik Eektro dengan bobot $7 \%$.

vi. Perhitungan dilanjutkan dengan mata pelajaran yang lain yaitu Matematika, Fisika, Biologi dan Kimia.

\subsection{Perhitungan Total Ranking/Prioritas Global}

Dari seluruh evaluasi yang dilakukan terhadap ke-6 kriteria yakni Nilai Bahasa Indonesia, Bahasa Inggris, Matematika, Biologi, Fisika, dan Kimia yang selanjutnya dikalikan dengan vektor prioritas. Dengan demikian, diperoleh tabel hubungan antara kriteria dan alternative.

Tabel 11.Matriks Hubungan antara Kriteria dan Alternatif

\begin{tabular}{|c|c|c|c|c|c|}
\hline Jurusan & $\begin{array}{c}\text { B.in } \\
\text { gg } \\
(\mathrm{m} 3)\end{array}$ & $\begin{array}{c}\text { Matemati } \\
\mathrm{ka} \\
(\mathrm{m} 4)\end{array}$ & $\begin{array}{c}\text { Fisi } \\
\mathrm{ka} \\
(\mathrm{m} 5)\end{array}$ & $\begin{array}{c}\text { Biolo } \\
\mathrm{gi} \\
(\mathrm{m} 6)\end{array}$ & $\begin{array}{c}\text { Kim } \\
\mathrm{ia} \\
(\mathrm{m} 7)\end{array}$ \\
\hline $\begin{array}{c}\text { T.Informat } \\
\text { ika }\end{array}$ & 0.46 & 0.36 & 0.15 & 0.26 & 0.13 \\
\hline T.Industri & 0.07 & 0.15 & 0.06 & 0.51 & 0.26 \\
\hline T.Mesin & 0.2 & 0.06 & 0.15 & 0.13 & 0.5 \\
\hline T.Sipil & 0.2 & 0.06 & 0.57 & 0.05 & 0.03 \\
\hline T.Elektro & 0.07 & 0.36 & 0.06 & 0.05 & 0.07 \\
\hline
\end{tabular}

Untuk mencari total ranking masing-masing alternatif dari proses seleksi adalah dengan cara mengalikan faktor evaluasi masing-masing alternatif dengan faktor bobot kriteria yaitu dengan mengalikan matriks 3.26 dengan tabel 
3.6 Sehingga dapat digambarkan dalam bentuk matriks yaitu sebagai berikut.

Tabel 12.Matriks Perhitungan Total

\begin{tabular}{|c|c|c|c|c|c|c|}
\hline Jurusan & $\begin{array}{l}\text { B.ing } \\
\operatorname{gr}(\mathrm{m} 1 \\
\left.*_{\mathrm{m} 3}\right)\end{array}$ & $\begin{array}{c}\text { Mat } \\
\text { ema } \\
\text { tika } \\
(\mathrm{m} 1 \\
*_{\mathrm{m}} \\
4)\end{array}$ & $\begin{array}{c}\text { Fisika } \\
\text { (m1* } \\
\text { m5 }\end{array}$ & $\begin{array}{l}\text { Biol } \\
\text { ogi } \\
(\mathrm{m} 1 \\
*^{2} 6\end{array}$ & $\begin{array}{c}\text { Kimi } \\
\text { a } \\
(\mathrm{m} 1 * \\
\mathrm{m} 7)\end{array}$ & Total \\
\hline $\begin{array}{l}\text { T.Infor } \\
\text { matika }\end{array}$ & $\begin{array}{c}0.048 \\
3\end{array}$ & $\begin{array}{c}0.03 \\
78\end{array}$ & $\begin{array}{c}0.006 \\
9\end{array}$ & $\begin{array}{c}0.06 \\
37\end{array}$ & $\begin{array}{c}0.06 \\
461\end{array}$ & $\begin{array}{c}0.221 \\
31\end{array}$ \\
\hline $\begin{array}{c}\text { T.Indust } \\
\text { ri }\end{array}$ & $\begin{array}{c}0.007 \\
35 \\
\end{array}$ & $\begin{array}{l}0.01 \\
575 \\
\end{array}$ & $\begin{array}{c}0.002 \\
76 \\
\end{array}$ & $\begin{array}{r}0.12 \\
495 \\
\end{array}$ & $\begin{array}{r}0.12 \\
922 \\
\end{array}$ & $\begin{array}{c}0.280 \\
03 \\
\end{array}$ \\
\hline T.Mesin & 0.021 & $\begin{array}{c}0.00 \\
63 \\
\end{array}$ & $\begin{array}{c}0.006 \\
9 \\
\end{array}$ & $\begin{array}{r}0.03 \\
185 \\
\end{array}$ & $\begin{array}{c}0.24 \\
85 \\
\end{array}$ & $\begin{array}{c}0.314 \\
55 \\
\end{array}$ \\
\hline T.Sipil & 0.021 & $\begin{array}{c}0.00 \\
63 \\
\end{array}$ & $\begin{array}{c}0.026 \\
22 \\
\end{array}$ & $\begin{array}{l}0.01 \\
225 \\
\end{array}$ & $\begin{array}{r}0.01 \\
491 \\
\end{array}$ & $\begin{array}{c}0.080 \\
68 \\
\end{array}$ \\
\hline $\begin{array}{c}\text { T.Elektr } \\
\text { o }\end{array}$ & $\begin{array}{c}0.007 \\
77\end{array}$ & $\begin{array}{c}0.03 \\
78 \\
\end{array}$ & $\begin{array}{c}0.002 \\
76 \\
\end{array}$ & $\begin{array}{l}0.01 \\
225 \\
\end{array}$ & $\begin{array}{c}0.03 \\
479 \\
\end{array}$ & $\begin{array}{c}0.095 \\
37 \\
\end{array}$ \\
\hline
\end{tabular}

Dari perhitungan pada masing-masing alternatif tersebut diperoleh:
a. Teknik Informatika $=0.22$
b. Teknik Industri $\quad=0.28$
c. Teknik Mesin $\quad=0.31$
d. Teknik Sipil $\quad=0.08$
e. Teknik Elektro $\quad=0.09$

Dari hasil perhitungan diatas di dapatkan hasil presentase dan diperoleh ranking dari penetapan jurusan study lanjut fakultas teknik,sebagai berikut :

a. Peringkat $1=$ Teknik Mesin dengan persentase $31 \%$

b. Peringkat $\mathbf{2}=$ Teknik Industri dengan persentase $28 \%$

c. Peringkat $3=$ Teknik Informatika dengan persentase $22 \%$

d. Peringkat $4=$ Teknik Elektro dengan persentase $9 \%$

d. Peringkat $5=$ Teknik Sipil dengan persentase $8 \%$

\subsubsection{Diagram Use Case Sistem yang Diusulkan}

Diagram use case merupakan sebuah alur kerja sistem dengan cara yang sangat sederhana, dimana menggambarkan fungsi utama dari sistem dan berbagai jenis pengguna yang dikembangkan, sebagaimana gambar 2 , berikut:

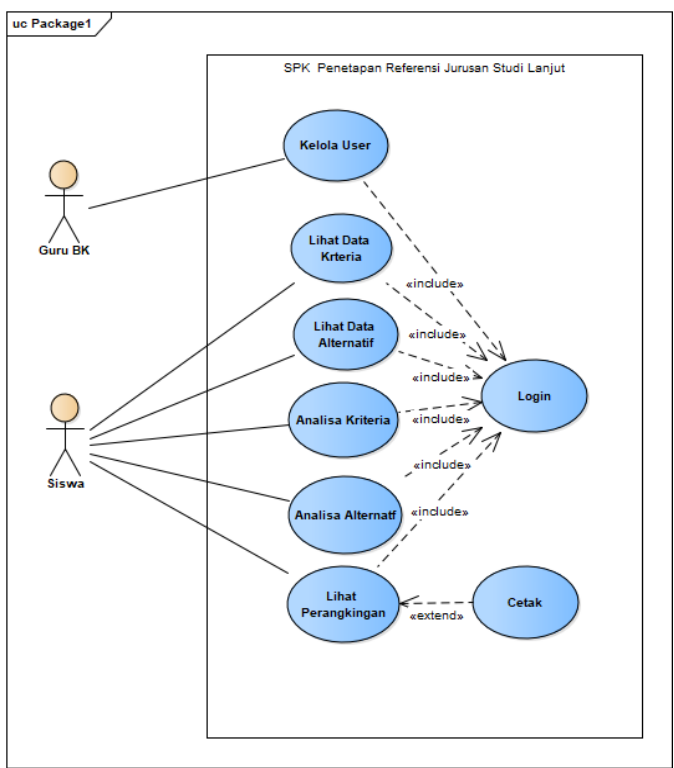

Gambar 3. Use Case Diagram SPK

\subsubsection{Diagram Sequence}

Sequence diagram merupakan sebuah diagram yang menggambarkan kolaborasi antar beberapa objek dengan dinamis sehingga dapat dipahami alur jalannya sebuah sistem.

Berikut ini 3 buah sequence diagram dari SPK yang dikembangkan pada penelitian ini:

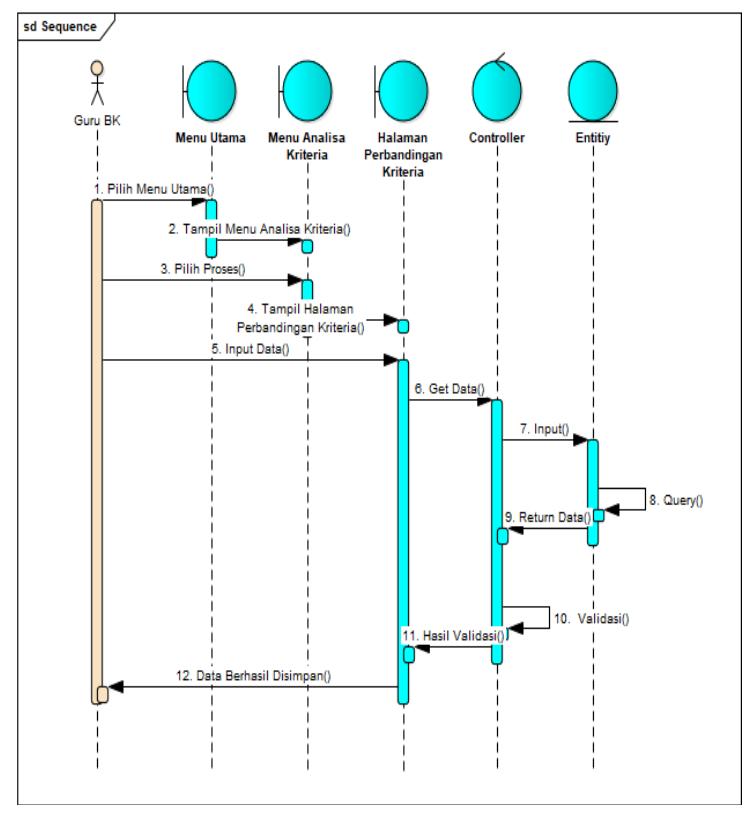

Gambar 4. Sequance Diagram Analisa Kriteria 


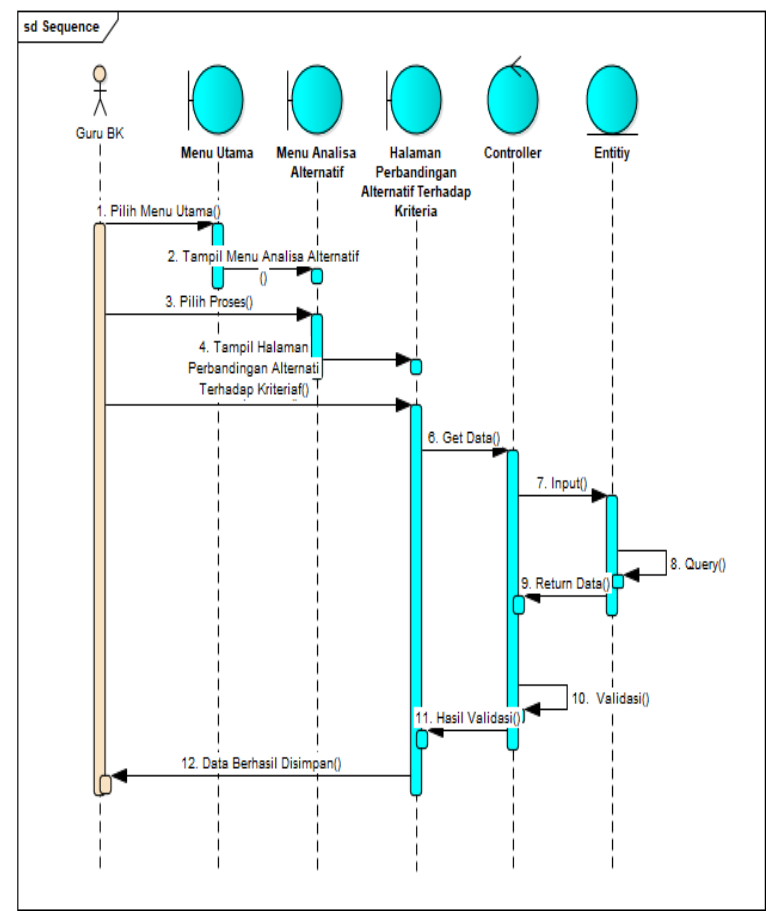

Gambar 5. Sequance Diagram Analisa Alternatif

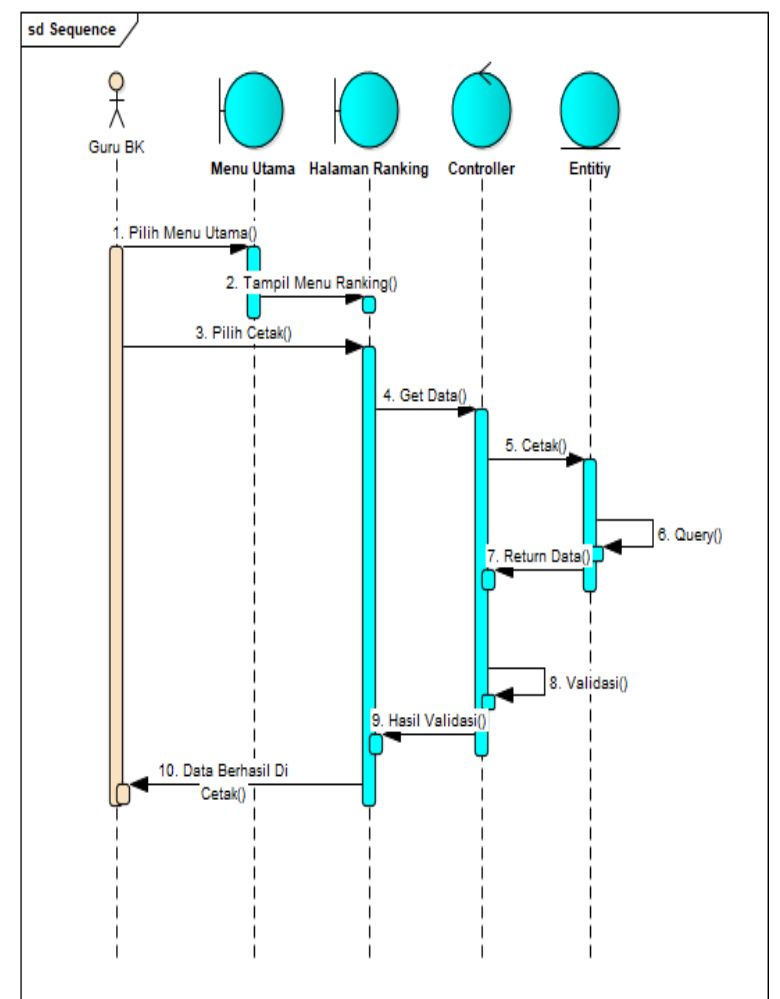

Gambar 6. Sequance Diagram Hasil Akhir SPK

\subsubsection{Class Diagram SPK}

Class Diagram merupakan pemodelan statis yang menggambarkan struktur dan deskripsi dari semua class dimana terdapat atribut table dan operasi (methodes) dalam sistem yang dikembangkan. Class diagram dari pengembangan SPK dalam penelitian ini terdapat dalam gambar 7 berikut ini:

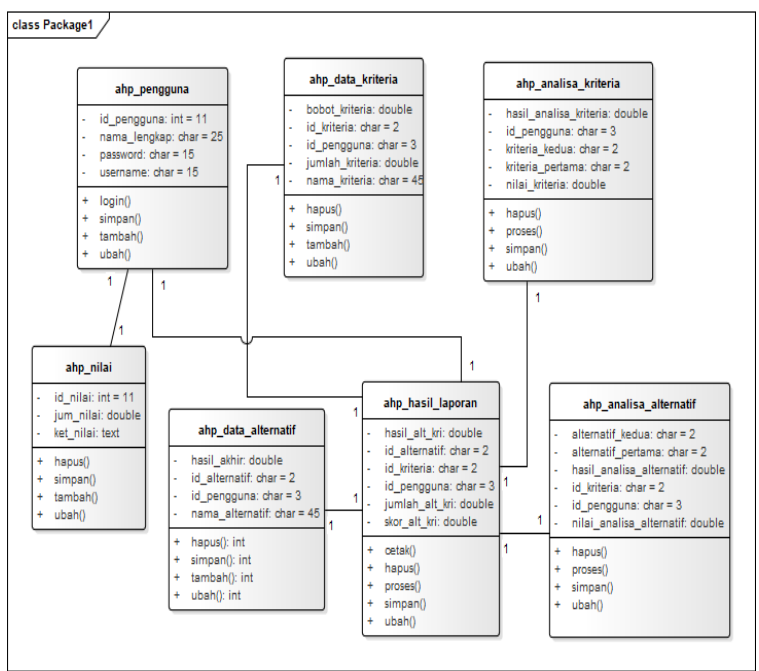

Gambar 7. Class Diagram Hasil Akhir SPK

\section{Tampilan Aplikasi SPK yang Dihasilkan}

Gambar dibawah merupakan tampilan antar muka aplikasi SPK yang dihasilkan dari penelitian ini:

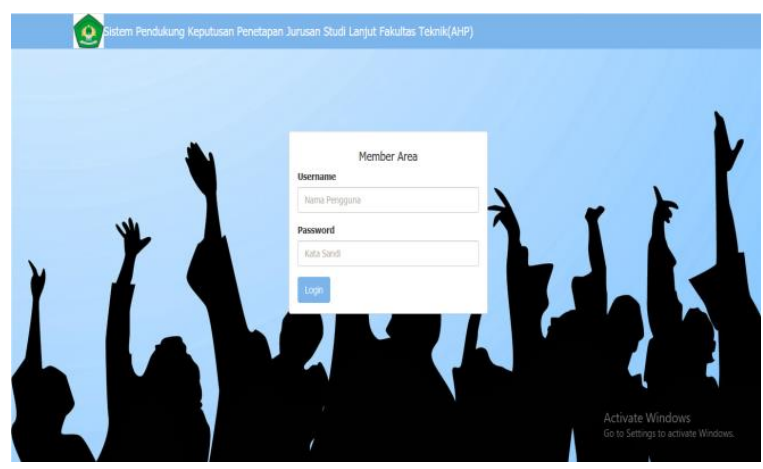

Gambar 8. Tampilan Menu Login

Gambar 8 menampilkan tampilan awal aplikasi, dimana pengguna diwajibkan memasukan user name dan password jika ingin mesuk ke aplikasi SPK yang dikembangkan. 


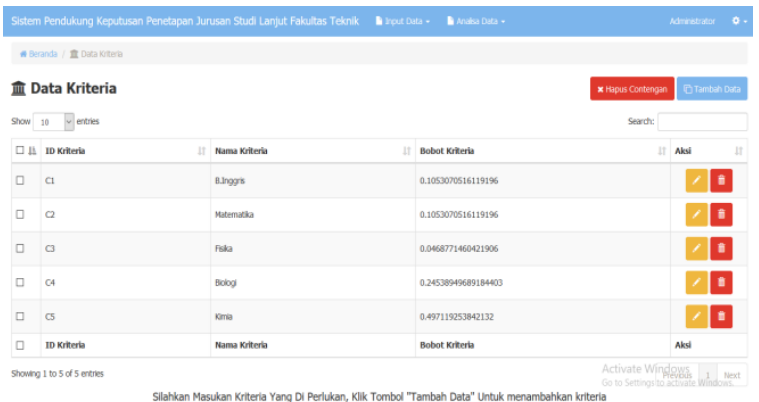

Gambar 9. Tampilan Menu Kelola Kriteria

Gambar 9 menampilkan daftar mata pelajaran yang digunakan sebagai kriteria dalam perhitungan SPK dan hasil perhitungan matrik faktor pembobotan kriteria yang didapat dari perhitungan data nilai siswa yang dimasukan pada masing-masing mata pelajaran kriteria.

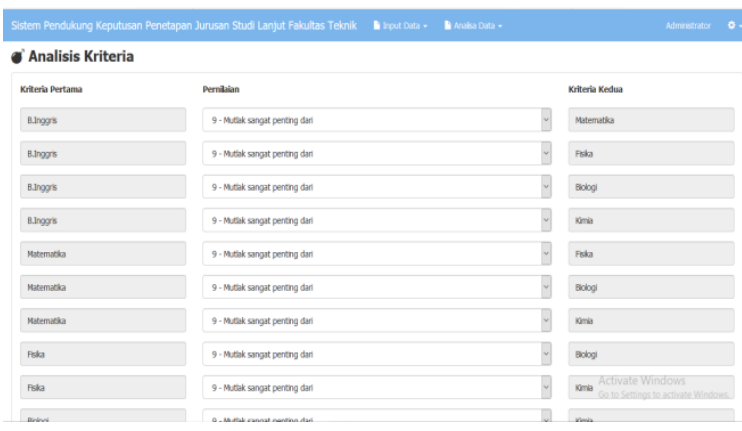

Gambar 10. Tampilan Menu Analisa Kriteria

Gambar 10 menampilkan daftar perbandingan kriteria (antar mata pelajaran) yang digunakan dalam perhitungan SPK pemilihan studi lanjut jurusan IPA. Perbandingan kriteria (antar mata pelajaran) ditentukan berdasarkan hasil wawancara dari beberapa kaprodi teknik di UMT yang menjadi narasumber penelitian ini.

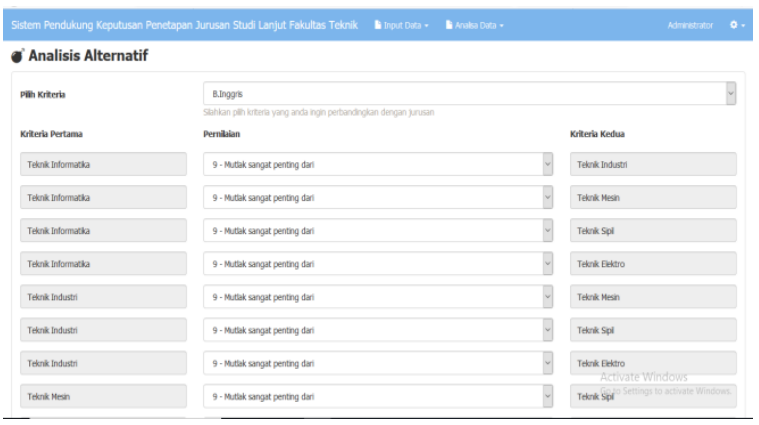

Gambar 11. Tampilan Menu Analisa Alternatif

Gambar 11 menampilkan daftar perbandingan kriteria (mata pelajaran pada setiap prodi) yang digunakan dalam perhitungan SPK pemilihan studi lanjut jurusan IPA. Perbandingan kriteria (mata pelajaran pada setiap prodi) ditentukan berdasarkan hasil wawancara dari beberapa kaprodi teknik di UMT yang menjadi narasumber penelitian ini.

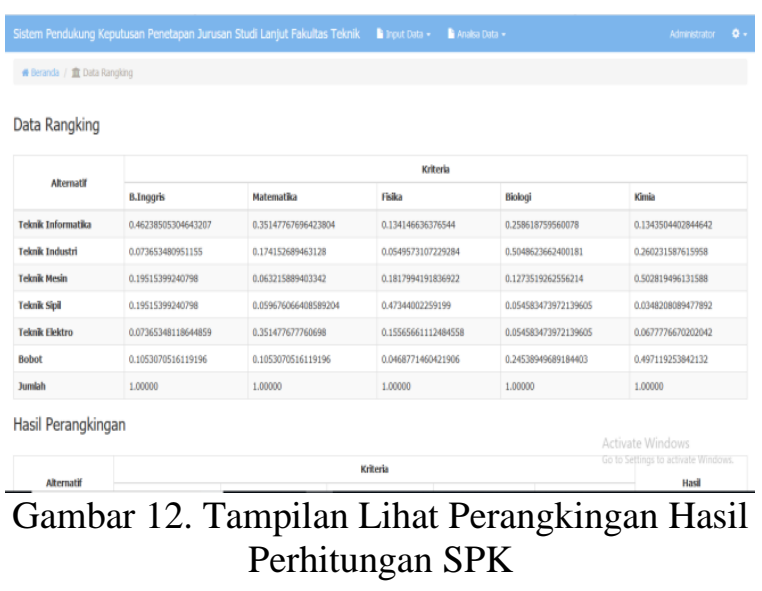

Gambar 12 menampilkan daftar hasil perhitungan akhir perangkingan SPK jurusan teknik yang paling sesuai dengan siswa yang bersangkutan.

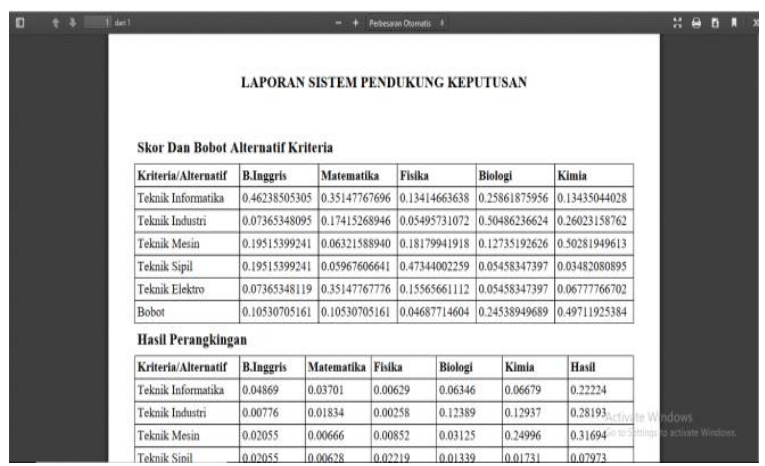

Gambar 13. Tampilan Cetak Laporan Hasil Perangkingan Perhitungan SPK

Gambar 13 menampilkan laporan daftar hasil perhitungan akhir perangkingan SPK jurusan teknik yang paling sesuai dengan siswa yang bersangkutan dalam bentuk tabel hasil perhitungan metode AHP, laporan ini dapat di cetak/print. 


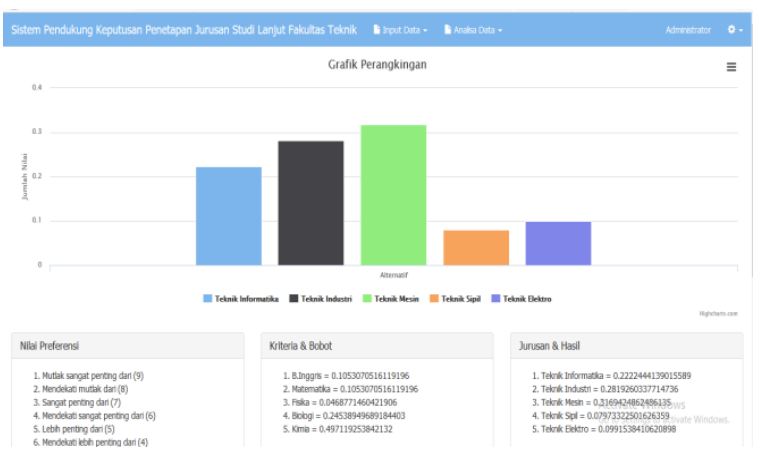

Gambar 14. Dashboard Aplikasi SPK

Gambar 14 menampilkan Dashboard hasil perhitungan akhir perangkingan SPK jurusan teknik yang paling sesuai dengan siswa yang bersangkutan dalam bentuk diagram batang yang mempermudah pengguna melihat hasil perhitungan SPK yang dikembangkan, jurusan mana yang paling sesuai dengan siswa yang bersangkutan. Untuk contoh data yang dimasukan pada penelitian ini, siswa tersebut lebih disarankan mengambil jurusan teknik mesin dibandingkan teknik industri atau teknik informatika.

\subsubsection{Pengujian Aplikasi SPK}

Aplikasi SPK yang dihasilkan dari penelitian ini kemudian dimasukan data-data nilai siswa jurusan IPA sebagaicontoh yang peneliti dapatkan dari beberapa nara sumber penelitian. Hasil perhitungan aplikasi SPK yang dikembangkan kemudian diuji coba menggunakan black box testing, dengan hasil sebagai berikut:

Tabel 1. Pengujian Black Box

\begin{tabular}{|c|c|c|c|c|c|}
\hline No & Pengujian & Skenario Pengujian & $\begin{array}{c}\text { Detail } \\
\text { Pengujian }\end{array}$ & Hasil pengujian & $\begin{array}{c}\text { Hasil } \\
\text { Pengujian }\end{array}$ \\
\hline 1 & \multirow{2}{*}{$\begin{array}{l}\text { Menguji hak akses } \\
\text { pengguna }\end{array}$} & \multirow{2}{*}{$\begin{array}{l}\text { Mengisi user name, } \\
\text { password dengan } \\
\text { tidak legkap lalu } \\
\text { click log-in }\end{array}$} & $\begin{array}{c}\text { Isi user name } \\
\text { tanpa password }\end{array}$ & \multirow{2}{*}{$\begin{array}{l}\text { Sistem menolak } \\
\text { akses login }\end{array}$} & $\begin{array}{c}\text { Sesuai harapan } \\
(\text { valid })\end{array}$ \\
\hline 2 & & & $\begin{array}{l}\text { Isi password } \\
\text { tanpa user name }\end{array}$ & & $\begin{array}{l}\text { Sesuai harapan } \\
\text { (valid) }\end{array}$ \\
\hline 3 & \multirow{5}{*}{$\begin{array}{c}\text { Menguji fungsi } \\
\text { entry/edit/ delete } \\
\text { data } \\
\text { dari setiap menu } \\
\text { setting data aplikasi }\end{array}$} & \multirow{5}{*}{$\begin{array}{l}\text { Mengisi user } \\
\text { name,password } \\
\text { yang memiliki hak } \\
\text { akses sistem dengan } \\
\text { legkap dan benar } \\
\text { lalu click log-in. } \\
\text { Click menu setting } \\
\text { dan masukan data } \\
\text { master sistem }\end{array}$} & $\begin{array}{c}\text { Masuk menu } \\
\text { utama }\end{array}$ & $\begin{array}{c}\text { Dapat } \\
\text { melakukan } \\
\text { entry/edit/delete } \\
\text { data }\end{array}$ & $\begin{array}{l}\text { Sesuai harapan } \\
\text { (valid) }\end{array}$ \\
\hline 4 & & & $\begin{array}{c}\text { Masuk menu } \\
\text { data nilai }\end{array}$ & $\begin{array}{c}\text { Dapat } \\
\text { melakukan } \\
\text { entry/edit/ delete } \\
\text { data }\end{array}$ & $\begin{array}{l}\text { Sesuai harapan } \\
\text { (valid) }\end{array}$ \\
\hline 5 & & & $\begin{array}{l}\text { Masuk menu } \\
\text { Data kriteria }\end{array}$ & $\begin{array}{c}\text { Dapat } \\
\text { melakukan } \\
\text { entry/edit/ delete } \\
\text { data }\end{array}$ & $\begin{array}{l}\text { Sesuai harapan } \\
\text { (valid) }\end{array}$ \\
\hline 6 & & & $\begin{array}{c}\text { Masuk menu } \\
\text { data alternative }\end{array}$ & $\begin{array}{c}\text { Dapat } \\
\text { melakukan } \\
\text { entry/edit/ delete } \\
\text { data }\end{array}$ & $\begin{array}{l}\text { Sesuai harapan } \\
\text { (valid) }\end{array}$ \\
\hline 7 & & & $\begin{array}{c}\text { Masuk menu } \\
\text { Tambah } \\
\text { pengguna }\end{array}$ & $\begin{array}{c}\text { Dapat } \\
\text { melakukan } \\
\text { entry/edit/ delete } \\
\text { data }\end{array}$ & $\begin{array}{c}\text { Sesuai harapan } \\
\text { (valid) }\end{array}$ \\
\hline
\end{tabular}

\section{SIMPULAN DAN SARAN}

Kesimpulan yang dapat peneliti sampaikan sebagai berikut:

1. Kriteria dan pembobotan yang diperoleh dari nara sumber yaitu 5 kaprodi pada fakultas teknik Universitas Muhammadiyah Tangerang, membuat data perhitungan SPK metode AHP yang dihasilkan lebih akurat karena kriteria dan pembobotan tersebut bersumber dari praktisi yang sudah 
berpengalaman lebih dari 5 tahun terlibat dalam proses belajar-mengajar di prodi masing-masing.

2. Aplikasi SPK metode AHP yang dihasilkan penelitian ini telah dapat membantu guru BP (Bimbingan Konseling) untuk dapat memberikan referensi pemilihan jurusan studi lanjut di fakultas teknik kepada para siswa kelas XII IPA yang ingin melanjutkanpendidikan ke perguruan tinggi.

\section{REFERENSI}

[1] B. Kamal and G. D. Rahmadiane, "Pengaruh Persepsi, Akreditasi Prodi, Dan Promosi Terhadap Keputusan Memilih Program Studi Akuntansi Pada Politeknik Harapan Bersama," $J$. Inspirasi Bisnis dan Manaj., vol. 1, no. 2, p. 145, 2017, doi: 10.33603/jibm.v1i2.866.

[2] T. Handayani, A. Herdiansah, N. Hariyani, T. Nugroho, and T. Informatika, "Sistem Informasi Simpan Pinjam Studi Kasus Koperasi Kodanua Serang," JIKA UMT, vol. 4, no. 1, pp. 14-19, 2020.

[3] Y. Firmansyah and U. Udi, "Penerapan Metode SDLC Waterfall Dalam Pembuatan Sistem Informasi Akademik Berbasis Web Studi Kasus Pondok Pesantren Al-Habib Sholeh Kabupaten Kubu Raya, Kalimantan Barat," $J$. Teknol. dan Manaj. Inform., vol. 4, no. 1, 2017, doi: 10.26905/jtmi.v4i1.1605.

[4] D. Saraswat and B. K. Chaurasia, "AHP based trust model in VANETs," Proc. 5th Int. Conf. Comput. Intell. Commun. Networks, CICN 2013, pp. 391-393, 2013, doi: 10.1109/CICN.2013.86.

[5] N. Yaraghi, P. Tabesh, P. Guan, and J. Zhuang, "Comparison of AHP and Monte Carlo AHP under different levels of uncertainty," IEEE Trans. Eng. Manag., vol. 62, no. 1, pp. 122-132, 2015, doi: 10.1109/TEM.2014.2360082.
[6] A. Maffei, M. Onori, M. R. Khabbazi, J. Wikander, and E. Bergseth, "Assembly feature data instance modeling: Prototype implementation and outputs," 2017 Int. Conf. Mech. Syst. Control Eng. ICMSC 2017, pp. 343-347, 2017, doi: 10.1109/ICMSC.2017.7959498.

[7] S. . Pressman, Software Engineering: A Practitioner's Approach, 7th editio. New York: The McGraw-Hill Company, 2010.

[8] A. Nugroho, Analisis Perancangan Sistem Informasi dengan Metodologi Berorientasi Object, Edisi 1. Bandung: Informatika, 2010.

[9] H. W. . Prabowo, Menggunakan UML (Unified Modeling Language), Edisi 1. Bandung: Informatika, 2011.

[10] M. Rahmayu and R. K. Serli, "Sistem Pendukung Keputusan Pemilihan Jurusan pada SMK Putra Nusantara Jakarta Menggunakan Metode Analytical Hierarchy Process (AHP)," Simetris J. Tek. Mesin, Elektro dan Ilmu Komput., vol. 9, no. 1, pp. 551-564, 2018, [Online]. Available: https://jurnal.umk.ac.id/index.php/simet/ article/view/2022.

[11] A. S. Irawan, "Sistem Pendukung Keputusan Pemilihan Jurusan di SMA Islam Sudirman Ambarawa Mengunakan Metode Analytical Hierarchy Process (AHP)," J. Mhs. STEKOM Semarang, vol. 1, no. 1, pp. 1-9, 2014.

[12] F. Frieyadie and S. M. Ramadhan, "Penerapan Metode AHP Untuk Membantu Siswa Memilih Jurusan Yang Tepat Di SMK," J. RESTI (Rekayasa Sist. dan Teknol. Informasi), vol. 2, no. 3, pp. 662-667, 2018, doi: 10.29207/resti.v2i3.396.

[13] Jogiyanto, Analisis dan Desain Sistem Informasi. Yogyakarya: Andi Offset, 2010. 